Estudios de

lingüística inglesa aplicada

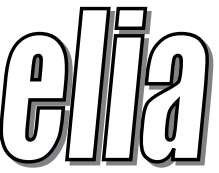

\title{
KEY CONCEPTS IN APPLIED LINGUISTICS / \\ CONCEPTOS CLAVE DE LA LINGÜÍSTICA APLICADA
}

\section{TECHNOLOGY-MEDIATED L2 TEACHING}

\section{Marta González-Lloret}

University of Hawai 'i, Manoa, USA

marta@hawaii.edu

DOI: http://dx.doi.org/10.12795/elia.2016.i16.06

The interest in technologies and innovations in language learning is certainly not an isolated phenomenon in today's education arena. Many students in prosperous parts of the world consider tablets, e-books, and smartphones essential to their daily life. They are known as the Net Generation (or Generation Z, iGeneration) and were born in the early 2000s or later. This generation is what Prensky (2001) termed "digital natives" and technology has shaped this generation's literacies, their ways of being in and with the world, and their cognitive and learning processes (Rosen, 2010; Thorne, 2013). This technologization of our youth requires reconsidering the way we teach and the training of future teachers (Nussbaum-Beach \& Hall, 2012) including language teachers. 
The term 'technology-mediated L2 teaching' is a natural evolution from the better known 'CALL (computer-assisted Language Learning)' term. Today, the inclusion of technology is not bound by computers anymore. Mobile devices are now routinely employed in the teaching of languages and their ubiquitous use is integrated within teaching (although one could argue that anything with a microprocessor is a computer).

This initial excitement and motivation for integrating new technologies in the classroom is not sufficient to make them effective tools for language learning. It is essential that they be guided by curricular principles based on research on education and language development in their design, use, and evaluation (González-Lloret \& Ortega, 2014).

In practical terms, incorporating technology into the L2 classroom should facilitate those aspects of language acquisition that we know are important to develop communicative competence: mainly, input that is authentic, non-simplified, and comprehensible, and interactional output linked to the necessity of producing language in interaction, negotiating what we do not know, becoming aware of interactional patterns inherent to the L2, and developing intercultural competence. In addition, bringing technology into the language classroom can fulfill the important role of promoting electronic literacies, such as information literacy and multimedia literacy, to future citizens of a global and digitized world.

It is important to make a distinction between technology-enhanced L2 teaching and technology-mediated L2 teaching. The former refers to the incorporation of individual activities at discrete times during a language course, but the technology does not play a central role in the curriculum. Technology-mediated L2 teaching, however, emphasizes the mediating role that the technology has in the construction of learning. The technology is not only a tool to bring into the classroom; it shapes the way learning is structured, and it is central to the curriculum, from the conceptualization of a curriculum based on a needs analysis that includes technological needs, to materials development, and to the inclusion of technology instruction.

We can see early work on linking technologies to SLA principles in Chapelle (1998) and Doughty and Long (2003). Since then, an explosion 
of research on language and cultural acquisition aspects of different technologies, contexts, and uses has been reflected in multiple volumes and several journal venues: CALICO Journal, ReCALL, CALL, System, and Language Learning \& Technology. Today the research venues have expanded to the mainstream areas of language learning journals that often publish studies with a technological component (e.g., Special Issue in the Modern Language Journal, 2009).

Some of the technologies that have been explored and incorporated into L2 teaching for their potential to promote language and cultural acquisition are Web 2.0 technologies such as chats, blogs, wikis, gaming environments, virtual worlds, etc. These tools are interesting because their interactive and dynamic nature allows teachers to harvest information, transform it and become part (with their students) of a collective intelligence. They provide countless sources of authentic input, both written and aural (e.g. blogs, podcasts, journals, fanfiction sites, forums where expert speakers interact), and allow for opportunities to produce output with a real audience and opportunities for feedback and interactive engagement both written and spoken (e.g. fanfiction website, wikis, forums, editorial comments, mobile messaging, social networks, audio and video chat, video creation, virtual worlds, multiplayer games).

Given the rapid changes in technology and innovation, predicting what tools students will need in the future is pure speculation. We can certainly find out what technologies students need to use currently, but predicting those that they will need after graduating in four, five, or ten years is almost impossible. For this reason, it is essential to focus research on the affordances of a tool, environment, or activity that promotes language learning, so that when technology changes, we can revisit whether these essential components are still intact (Chun, Kern \& Smith, 2016; González-Lloret \& Ortega, 2014). As an example of innovation applied to language learning (within a Task-based Language Teaching methodological framework), the European Digital Kitchen Project (Seedhouse, in press) developed a digital sensory kitchen environment where learners acquire language skills by cooking and interacting with a "smart kitchen" that recognizes their movements, uses of utensils, mistakes on measurements, 
etc. (Seedhouse, 2017; Seedhouse \& Knight, 2016).

The future of technology-mediated L2 teaching will probably follow an evolution, parallel to that of SLA, towards epistemological diversity and inclusion of new theories (e.g., emergentism, dynamic systems, complexity theories under the usage-based philosophy), incorporating new research agendas not yet addressed. In particular, it will include research topics incorporating social dimensions of second language learning such as issues of identity construction through technologies, the role that technology has in mediating knowledge, how we conceptualize privacy and social spaces, how knowledge is distributed, co-constructed, and shared through different media in time and space, what role the pragmatics of a language play in the design of the language curriculum, etc.

In addition, as technologies reach populations that have not traditionally been part of SLA studies, there will be more variety in studies. Technology is now pervasive among very young children, and we need studies of pre-school and school-age children learning language mediated through innovation in and out of institutional settings (e.g., Butler, 2015). In addition, as people's capacities to engage in technology evolve, we will need studies of people learning languages with high and low computer literacies, as well as multilinguals engaging with different technologies. Finally, of great importance for the successful implementation of technology in the L2 classroom is teacher training and education. Without proper technological and methodological education, teachers revert back to the less-intimidating classroom resources that are familiar to them, leaving innovation behind. In conclusion, as technology becomes ubiquitous in our lives, its role will become crucial in the language classroom. It is essential then that researchers and educators evaluate new technologies available for their affordances to mediate language and culture learning.

\section{References}

Butler, Y. G. (2015). The use of computer games as foreign language learning tasks for digital natives. System, 54, 91-102. https://doi.org/10.1016/j. system.2014.10.010 
Chapelle, C. (1998). Multimedia CALL: Lessons to be learned from research on instructed SLA. Language Learning \& Technology, 2(1), 22-34 Retrieved March 4, 2002, from http://llt.msu.edu/vol2num1/article1/index.html.

Chun, D., Kern, R., \& Smith, B. (2016). Technology in Language Use, Language Teaching, and Language Learning. The Modern Language Journal, 100(S1), 64-80. https://doi.org/10.1111/modl.12302

Doughty, C., \& Long, M. H. (2003). Optimal psycholinguistic environments for distance foreign language learning. Language Learning and Technology, $7(3), 50-80$.

González-Lloret, M., \& Ortega, L. (2014). Towards technology-mediated TBLT: An introduction. In M. González-Lloret \& L. Ortega (Eds.), Technologymediated TBLT: researching technology and tasks (pp. 1-22). Amsterdam ; Philadelphia: John Benjamins Publishing Company.

Nussbaum-Beach, S., \& Hall, L. R. (2012). The connected educator: learning and leading in a digital age. Bloomington, IN: Solution Tree Press.

Prensky, M. (2001). Digital Game-Based Learning. McGraw-Hill.

Raith, T., \& Hegelheimer, V. (2010). Teacher development, TBLT and technology. In M. Thomas \& H. Reinders (Eds.), Task-based language learning and teaching with technology (pp. 154-175). London ; New York: Continuum.

Rosen, L. D. (2010). Rewired: understanding the iGeneration and the way they learn (1st ed). New York: Palgrave Macmillan.

Seedhouse, P. (Ed.). (2017). Task-Based Language Learning in a Real-World Digital Environment: The European Digital Kitchen. Bloomsbury Publishing.

Seedhouse, P., \& Knight, D. (2016). Applying Digital Sensor Technology: A Problem-Solving Approach. Applied Linguistics, 37(1), 7-32. https://doi. org/10.1093/applin/amv065

Thorne, S. L. (2013). Digital literacies. In M. Hawkins (Ed.), Framing languages and literacies: Socially situated views and perspectives (pp. 193-219). New York, NY: Routledge.

Thorne, S. L., Hellermann, J., Jones, A., \& Lester, D. (2015). Interactional practices and artifact orientation in mobile augmented reality game play. PsychNology Journal, 13(2-3), 259-286. 
Marta González-Lloret is a professor at the University of Hawai' $i$ Manoa where she obtained her $\mathrm{PhD}$ in Second Language Acquisition. She currently teaches in, and is chair of, the Spanish Division and is Associated Graduate Faculty of the Department of Second Language Studies. Her research interests lay at the intersections of technology and TBLT (Taskbased Language Teaching), technology and L2 pragmatics, conversation analysis for L2 interaction, teacher training, and assessment, especially performance-based assessment. She has published and given talks extensively in these topics and has recently (2016) published A Practical Guide to Integrating Technology into Task-based Language Teaching with Georgetown University Press. Currently, she is co-editing a volume titled Comunicación mediada por tecnologías: aprendizaje y enseñanza de la lengua extranjera that will be published by Equinox in 2017.

First version received: July 2016

Final version accepted: October 2016

ELIA 16, 2016, pp. 13-34 DOI: http://dx.doi.org/10.12795/elia.2016.i16.06 